IFN Working Paper No. 849, 2010

\title{
Exploring the Duration of EU Imports
}

\section{Wolfgang Hess and Maria Persson}




\title{
Exploring the Duration of EU Imports*
}

\author{
Wolfgang Hess ${ }^{\dagger} \quad$ Maria Persson ${ }^{\ddagger}$
}

August 24, 2010

\begin{abstract}
The objective of this paper is twofold. First, against the background of an existing empirical literature on the duration of trade which has found that international trade is often of strikingly short duration, we aim to establish whether or not EU imports from the rest of the world also are short-lived. Second, since there is at this point no clear commonly accepted theoretical explanation for these short trade durations, we seek to provide a thorough empirical description and analysis of the phenomenon, with the intention of thereby facilitating theoretical developments on the subject. We employ a rich data set of detailed imports to the EU15 countries from 140 exporters, covering the time period 1962-2006. Using these data, we begin by conducting a thorough descriptive analysis of the duration of EU imports. Thereafter, we perform a regression analysis using discrete-time duration models with proper controls for unobserved heterogeneity. We draw the conclusion that EU imports are indeed very short-lived - in fact, possibly more so than, for example, US imports. The median duration of EU imports is for example merely one year, and almost 60 percent of all spells cease during the first year of service. Among our empirical findings are (i) that the duration of trade remains stable across the long time period that we study; (ii) that short trade durations are the result of at least two processes: countries shifting between different suppliers but continuing to import a given product, and countries ceasing to import the product altogether; and (iii) that countries with a diversified export structure also will tend to have more long-lived export flows. In our formal regression, we are also able to find a set of explanatory variables that have statistically significant effects on the probability that trade flows die.
\end{abstract}

\section{JEL Classification: C41; F10; F14.}

Keywords: Duration of Trade; Survival; European Union; Discrete-Time Hazard Models

* This paper builds on the empirical part of Working Paper 2009:12, Department of Economics, Lund University, which was presented at the 2009 ETSG Conference in Rome and at seminars at Lund University and IFN in Stockholm. We would like to thank conference and seminar participants, and in particular Yves Bourdet, Joakim Gullstrand, Scott Hacker, Magnus Henrekson, Fredrik Sjöholm, and Fredrik Wilhelmsson for many valuable comments. We are also very grateful to Paul Linge and the LUNARC team for providing us access to very powerful computing resources. Financial support from the Jan Wallander and Tom Hedelius Foundation under research grant numbers P2006-0131:1, P2009-0189:1 and W2009-0352:1, and from the Marianne and Marcus Wallenberg Foundation is gratefully acknowledged.

${ }^{\dagger}$ Department of Economics, Lund University. E-mail: Wolfgang. Hess@nek.lu.se.

${ }^{\ddagger}$ Corresponding author: Department of Economics, Lund University, P.O. Box 7082, S-220 07 Lund, Sweden, and Research Institute of Industrial Economics (IFN). E-mail: Maria.Persson@nek.lu.se; Tel.: +46462224670 . 


\section{Introduction}

It is by now firmly established that not all country pairs trade all products all the time. A good deal of effort has been expended by trade economists in establishing the proper method of handling these "zeros" in the trade matrix, with few now attempting to ignore zero trade flows when it comes to the traditional question of explaining volumes of trade. ${ }^{1}$ The zeros have also been interpreted in their own right, and especially the question of what makes a trade flow go from zero to positive has been scrutinized. However, while researchers have used both country-level and firm-level data to focus on this issue of what makes countries or firms start to trade, much less attention has been payed to the question of what makes countries or firms stop trading. Nevertheless, this question is arguably as important to understand, because factors causing existing trade flows to die could be as much of an impediment to long-term trade growth as factors which prevent trade from occurring in the first place.

The question of whether trade flows survive or die is the focus of the emerging literature on the duration of trade. Tracing its roots to the seminal papers by Besedeš and Prusa (2006a,b), this literature uses the zeros in the trade matrix in a novel way. The time that passes between zeros - or, in other words, the number of years that a single trade flow survives from the first year of trade until the value of trade is again zero for this particular product - is measured, and the length of this spell constitutes the main object of study. The question asked is: can we identify factors which influence this duration of trade? Technically speaking, this is the same as asking what kind of factors influence the probability that a trade flow dies in a given period of time, given that it has survived up until that period.

The literature on the duration of trade is limited so far, but the empirical consensus that has been formed indicates that trade is indeed very short-lived. Besedeš and Prusa (2006a,b), for example, find that the median duration for US imports (at the 4-digit SITC level of aggregation) is merely two years. Nitsch (2009), using much more detailed data, finds that the median duration of German imports is two years. In other words, the conclusion from empirical studies so far is that most trade flows do not survive for very long.

However, as noted by several of the authors in the literature, such short trade durations are not entirely easy to reconcile with the commonly used theories about trade. In fact, with some possible exceptions, the trade theories that explicitly have something to say about the dynamics of trade would generally predict that trade patterns change very slowly. Once trade has actually begun, it should - theoretically speaking - survive for some time. This issue will be further discussed below.

\footnotetext{
${ }^{1}$ For various approaches to this issue, see e.g. Helpman et al. (2008) or Santos Silva and Tenreyro (2006).
} 
The purpose of this paper is twofold. First, we investigate empirically whether trade between countries within the European Union (EU) and the rest of the world is as shortlived as previous studies have found to be the case for American and German trade, for example. Given that the EU is the major trading partner for many of the world's countries - including many developing countries in need of economic growth - this question is important. Second, since there is at this point no clear, commonly accepted theoretical explanation for these short trade durations, we attempt to provide a general solid empirical description and analysis of the phenomenon, so as to provide theorists with improved means of formulating a plausible theoretical framework. We work towards these aims by employing a rich data set of detailed imports to the EU15 countries from 140 exporters, covering the period 1962-2006. Using these data, we both perform a thorough descriptive analysis of the duration of EU trade, and test the data in a regression analysis. In the latter, we build on the methodological results from Hess and Persson (2010) and apply econometrically appropriate discrete-time duration models rather than the previously used continuous-time Cox model. As argued theoretically and shown empirically in Hess and Persson (2010), using continuous-time methods - such as Cox models - when studying the duration of trade introduces serious risks of drawing misleading conclusions.

Our two main contributions to the literature consist of 1) a focus on the duration of $E U$ trade which has not been explicitly studied before; and 2) the usage of econometrically more appropriate discrete-time estimation methods rather than the continuous-time methods that typically have been used to search for determinants of the duration of trade. The nature of the data employed also gives rise to three additional contributions. First, the extended time period allows us to draw interesting conclusions about how the duration of trade has changed over time. Second, by comparing bilateral trade relationships with EU countries' aggregated imports we can illustrate that short trade durations seem to be the result of at least two separate economic processes: countries shifting between different suppliers and countries ceasing to import the product altogether. Third, we can use the exporter variation to conclude that export diversification is connected with longer trade durations.

The remainder of the paper is organized as follows. Section 2 offers an overview of the relevant empirical and theoretical literature. The data and empirical strategy are outlined in Section 3, followed by a descriptive analysis of the duration of EU imports in Section 4. Section 5 presents the regression analysis, and Section 6 summarizes and concludes.

\section{Previous Research}

\subsection{Empirical Papers on the Duration of Trade}

The literature pertaining to the duration of trade remains quite limited. One of the first papers to directly ask the question "how long do trade relationships last?" is Besedeš and 
Prusa (2006a). Using data on US imports at the 7-digit (US Tariff Schedule) level from 160 exporters for 1972-1988 to estimate Kaplan-Meier survival functions, their results suggest that the duration of exports to the US is in general very short. ${ }^{2}$ The estimated survival rate is 67 percent for the first year, but rapidly decreasing thereafter.

Besedeš and Prusa (2006b) make use of the same US import data as Besedeš and Prusa (2006a). Basing their investigation on the model by Rauch and Watson (2003), they add the Rauch (1999) classification of goods into homogeneous, reference-priced and differentiated. Applying a Cox proportional hazards model, which - unlike the KaplanMeier methodology - enables them to include explanatory variables in their analysis, they find that differentiated products have lower hazard rates than homogeneous goods. They also find that, within each product type, the larger the initial value of the trade flow, the longer the duration. Besedeš (2008) builds on this work, and investigates further the implications of the model by Rauch and Watson (2003).

Nitsch (2009) examines the duration of German imports at the 8-digit (Combined Nomenclature) product level, using data from Eurostat for 1995-2005. Employing a stratified Cox proportional hazards model, he investigates the effects of numerous regressors on the hazard rate. The conclusions are that exporter characteristics (such as GDP and language), product characteristics (such as unit values) and market characteristics (such as the import value, and market share) affect the duration of German imports.

Besedeš and Prusa (2007) focus on the extensive and intensive margins of trade. Using data on manufacturing exports at the 4-digit SITC (Revision 1) level from 46 countries to 181 importers for 1975-2003, they decompose export growth into three parts: establishing trade with new partners and markets; having relationships survive or persist; and deepening existing relationships. ${ }^{3}$ Estimating Kaplan-Meier survival functions for each of the individual exporters, they find that export duration is very brief, with the median being 1-2 years.

Brenton, Saborowski and von Uexküll (2009) look at the duration of export flows at the 5-digit SITC level from 82 exporters to 53 importers over the period 1985-2005, using a discrete-time complementary log-log model to estimate the effects of various explanatory variables on the hazard rate. Brenton, Pierola and von Uexküll (2009) use a Cox model to estimate determinants of trade in a data set with 44 exporters and 56 importers over a 21-year period. Fugazza and Molina (2009) use an extended version of the Cox model where the estimation coefficients are allowed to vary over duration time, and estimate determinants of trade duration among 96 trading countries for the period 1995-2004.

Among the previous papers on the duration of country-level trade flows there exist a number of similarities. Not only do they all find the existence of short trade durations,

\footnotetext{
${ }^{2}$ These results are largely confirmed by using the 10-digit (Harmonized System) US imports from 180 exporters for 1989-2001.

${ }^{3}$ The former is regarded as affecting growth at the extensive margin, while the latter two at the intensive margin.
} 
but the majority also study much shorter time periods while using estimation methods that introduce risk of biases and misleading conclusions (see Hess and Persson, 2010, for a discussion). In addition none choose to focus on EU imports, with only a few (e.g. Brenton, Saborowski and von Uexküll, 2009, and Fugazza and Molina, 2009) electing to include EU15 importers among the many other countries in their sample.

\subsection{Other Relevant Research}

The consensus among papers looking at the duration of trade using country-level data is that trade typically is quite short-lived: countries export for a few years, leave the export market, and then re-enter. This empirical phenomenon is largely unexplained by existing trade theories, which are not always good at capturing dynamics. One trade theory that explicitly considers how trade patterns evolve over time is the product-cycle theory (Vernon, 1966). This theory does not, however, seem to be consistent with very short trade durations (see Besedeš and Prusa, 2006a, for a discussion). The search-cost theory proposed by Rauch and Watson (2003) is another candidate, and it has been shown by Besedeš and Prusa (2006b) and Besedeš (2008) to have some explanatory power. However, the most natural setting for thinking about entry and exit in the export market may be the literature on sunk costs. In this literature, models based on representative ${ }^{4}$ as well as heterogeneous ${ }^{5}$ firms explain how the existence of sunk costs for exporting creates a history-dependence in firms' export decisions. Once a firm has paid the sunk costs for entering the export market, such as costs associated with collecting information about potential buyers or establishing distribution channels, it may choose to remain an exporter even when it faces a temporary loss from exporting. The reason is that the firm then avoids paying an additional re-entry cost if it foresees future profits from exporting. The importance of sunk costs in firms' export decisions has been empirically verified by papers such as Roberts and Tybout (1997) and Bernard and Jensen (2004). Hence, given that sunk costs are indeed important, one would expect long trade durations because once firms have entered the market, they will be prone to remain there. Likewise, if they have left the market, they will hesitate to re-enter. However, this is not what the existing literature on trade duration has found for, in particular, US and German trade. Here, trade flows have been found to follow a cycle whereby positive flows exist for only a few years, then fall to zero before again becoming positive. One possible explanation for these short trade durations is that even though sunk costs are indeed important for starting exports of a product to the first trade partner, there may be small additional costs for exporting to another trade partner. However, it is also important in this context to emphasize that (discrete-time) duration models estimate the probability that a trade relationship, which is already established, fails in a particular time interval. Hence, the effects of trade costs

\footnotetext{
${ }^{4}$ See e.g. Baldwin (1988), Baldwin and Krugman (1989), and Dixit (1989).

${ }^{5}$ See e.g. Melitz (2003), Bernard et al. (2003), or Yeaple (2005).
} 
on the likelihood of starting a new trade relationship are not captured. Since the theory about sunk costs is concerned with a firm's decision of whether or not to export in a certain period, given that the firm did or did not export in the previous period, it is therefore not entirely straightforward to derive hypotheses about the impact of trade costs on the likelihood that a trade relationship dies.

To summarize, we would argue that there is at this point no given theoretical model that can fully explain the observed short trade durations. This conclusion is shared by, for instance, Brenton, Saborowski and von Uexküll (2009). Our aim in this paper is therefore to contribute to the building of an empirical foundation for developing such theoretical models.

\section{Data}

To study the duration of exports from a broad range of exporters to the European Union, we use mirror data from the UN Comtrade Database on imports to the EU from 1962 to $2006 .{ }^{6}$ The trade data used are at the 4-digit level, classified according to the Standard International Trade Classification (SITC), Revision 1. Using this relatively aggregated 4-digit data has two advantages. As noted by Besedeš and Prusa (2006b), unlike customs product codes, according to which more disaggregated data are usually classified, products in the SITC are not reclassified from year to year, implying that we have one less source of censoring to worry about. Further, data at a relatively high level of aggregation will yield more conservative estimates. In other words, if we do find short trade spells using relatively aggregated data, we can be more confident that this mirrors an economically significant phenomenon. This follows Besedeš and Prusa (2007) who use the same type of data in their analysis.

The sample of exporters consists of all countries that at some point during the observation period exported to the EU. It is important to note, however, that two groups of countries have been excluded from the sample. First, we exclude all EU27 countries as exporters, since we are primarily interested in studying the duration of the EU's trade with the rest of the world. Second, we also exclude former Soviet republics and South East European transition economies, because trade in these centrally planned economies was arguably driven by political rather than economical factors. Following this, we obtain data on EU imports from 140 exporters, covering a broad range of income levels. The sample of exporting countries is shown in Table A.1 in the Appendix.

Our main empirical strategy is to study the duration of bilateral trade relationships. As importing countries we consider all EU15 countries during the whole observation period

\footnotetext{
${ }^{6}$ For simplicity, we will refer to the "European Union", though, of course, this term will not be formally correct in some instances.
} 
from 1962-2006. ${ }^{7}$ By studying a longer time period than any previous paper in the literature we are able to both obtain more observations and investigate whether trade dynamics change over time. As it has been argued by Besedeš and Prusa (2007) that the data quality might be lower for the earlier years of our period under scrutiny, we therefore also analyze different sub-periods with later starting dates to ensure that our results do not depend on the specific time period chosen. We note, however, that using mirror import data reported by EU countries will very likely lead to far fewer data problems than employing export data reported by a large range of countries (including many developing countries), as done by Besedeš and Prusa (2007). Thus, our main strategy is to use data from the whole time period.

For each calendar year, we observe the value of any EU country's imports from a given country at the 4-digit product level. For every combination of importing country, exporting country, and traded product (hereafter referred to as a trade relationship), we calculate the duration of trade as the number of consecutive years with non-zero imports. These different spells of trade constitute the core units of analysis in our empirical study. The number of spells differs from the number of trade relationships since any of the trading parties may choose to terminate the trade relationship and revive it at a later point in time. Henceforth, we will refer to such reoccurring trade relationships as multiple spells of service.

In the following, we will use these data to first perform a descriptive analysis of the duration of EU imports, and then search for potential determinants of trade durations in a formal regression analysis.

\section{Describing the Duration of EU Imports}

In our aim to explore the duration of EU trade, we start by performing a thorough descriptive analysis. Table 1 offers some initial summary statistics as to the length of EU import flows.

Noting first that there is a large number of observed spells (over one million), Table 1 shows that the median duration of a spell in our benchmark data is only one year. The most common scenario is, in other words, for an exporter to go from not exporting the product to a particular EU country to entering the market for at most one year, only to then leave the market again. The mean duration of slightly more than three years is also rather low. Comparing these figures with what has been found for other countries, EU imports appear to be at least as short-lived. For instance, Besedeš and Prusa (2006a) find

\footnotetext{
${ }^{7}$ Since many EU15 countries join the EU after 1962, we include a dummy variable in our regressions, that indicates for every year of a spell whether the respective importing country has already joined the EU or not. It should be noted that, since Belgium and Luxembourg are treated as one trading block in the statistics, we have data for 14 importers in practice.
} 
Table 1: Summary Statistics

\begin{tabular}{|c|c|c|c|c|c|c|}
\hline & \multicolumn{2}{|c|}{$\begin{array}{l}\text { Observed spell } \\
\text { length in years }\end{array}$} & \multirow{2}{*}{$\begin{array}{c}\text { Total } \\
\text { number } \\
\text { of spells }\end{array}$} & \multirow{2}{*}{$\begin{array}{l}\text { Fraction } \\
\text { of spells } \\
\text { censored }\end{array}$} & \multirow{2}{*}{$\begin{array}{l}\text { Total number } \\
\text { of trade } \\
\text { relationships }\end{array}$} & \multirow{2}{*}{$\begin{array}{c}\text { Total number } \\
\text { of product } \\
\text { codes }\end{array}$} \\
\hline & Mean & Median & & & & \\
\hline \multicolumn{7}{|l|}{ Benchmark data } \\
\hline All spells & 3.30 & 1 & 1000108 & 0.14 & 364806 & 625 \\
\hline \multicolumn{7}{|l|}{ Spell definitions } \\
\hline Single spell & 4.42 & 1 & 136996 & 0.19 & 136996 & 625 \\
\hline First spell & 3.00 & 1 & 364806 & 0.07 & 364806 & 625 \\
\hline \multicolumn{7}{|l|}{ Gap-adjusted spells } \\
\hline 1-year gap & 4.21 & 1 & 756659 & 0.18 & 361161 & 625 \\
\hline 2-year gap & 4.86 & 1 & 641746 & 0.21 & 358374 & 625 \\
\hline 3-year gap & 5.36 & 2 & 572824 & 0.23 & 356328 & 625 \\
\hline \multicolumn{7}{|c|}{ Different cut-off levels for trade } \\
\hline 1 million USD & 3.46 & 1 & 851718 & 0.14 & 335282 & 625 \\
\hline 5 million USD & 3.85 & 1 & 490284 & 0.16 & 249485 & 625 \\
\hline 10 million USD & 4.00 & 1 & 364599 & 0.17 & 203817 & 625 \\
\hline \multicolumn{7}{|c|}{ Level of product aggregation } \\
\hline 3-digit SITC & 3.60 & 1 & 490217 & 0.14 & 163995 & 182 \\
\hline 2-digit SITC & 3.98 & 1 & 222660 & 0.15 & 69213 & 61 \\
\hline 1-digit SITC & 5.11 & 2 & 51179 & 0.17 & 14199 & 10 \\
\hline
\end{tabular}

a corresponding median duration of two years for US imports at the same level of data aggregation (with a mean of over four years), and Nitsch (2009), who uses much more detailed data, find a median duration of 2 years for German imports. Thus, the data suggest that EU imports are actually even more short-lived than those for other countries.

To be able to describe the trade flows with more information than a mere median or mean value will allow, we also plot a descriptive survivor function. Figure 1(a) illustrates the distribution of EU import durations. The $x$-axis plots the observed spell length, and the $y$-axis plots the fraction of observations whose observed spell of service exceeds a given length. Focusing for now on the benchmark data used in the baseline estimations - as depicted by the solid line - almost 60 percent of all spells cease during the first year of service. Approximately 75 percent of all trade flows terminate within the first two years, and more than four in five trade relationships only last a maximum of three years. Less than ten percent of all relationships survive the first ten years. Thus, the vast majority of 
spells will only last for at most a few years, and only a small fraction can be characterized as long-lasting. These are remarkable results when considering both the high level of product aggregation (encompassing a total of only 625 products) and the usage of data at the country level, which would suggest fewer movements in and out of the market, rather than the firm level.

Figure 1: Descriptive Survivor Functions

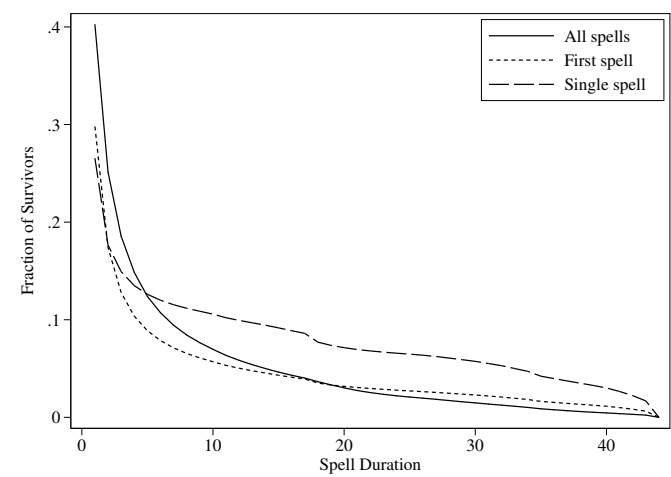

(a) Spell definitions

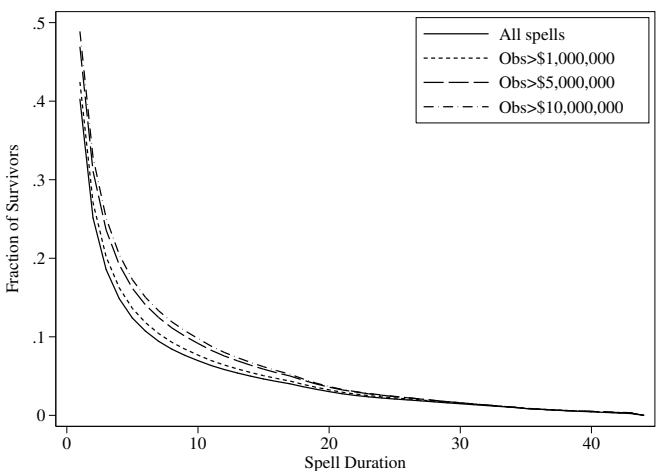

(c) Different cut-off points

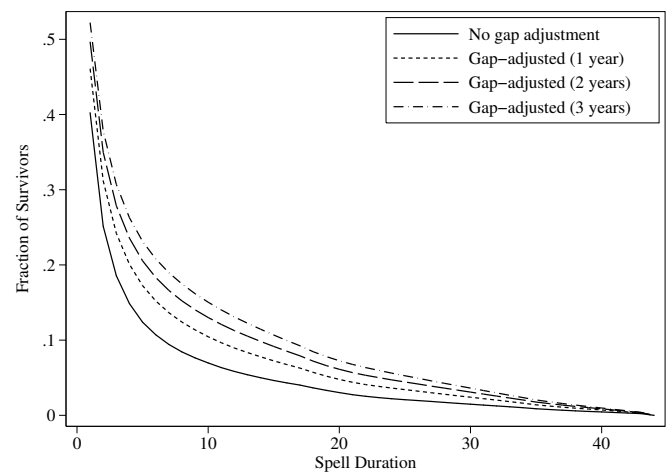

(b) Gap-adjustments

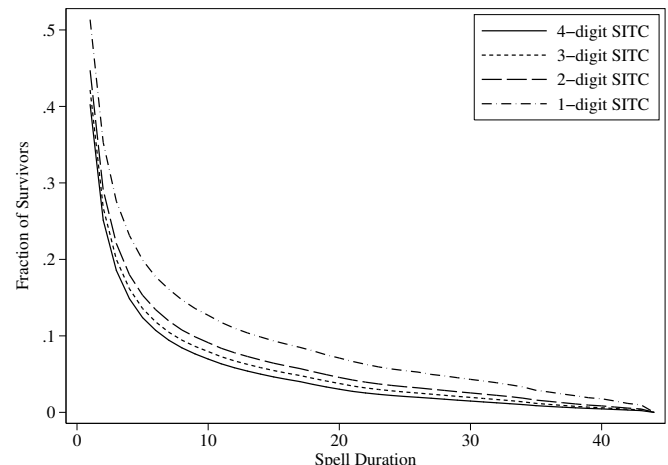

(d) Levels of data aggregation

Our conclusion so far is that EU imports are very short-lived. However, it could be argued that this is merely a result of the way that trade is being measured. To confirm the robustness of the results, we investigate whether using other ways to define spells or measure trade alters our conclusions. As illustrated in Table 1, changing the definition of a spell only has minor effects on the median and mean durations. First, we use only single spells, i.e. observations where a specific exporter-importer-product combination has only one single coherent period of trade. Second, we disregard all higher-order spells to see whether the first observed spell has different characteristics. In both cases, even though the number of observations is drastically reduced (implying that we have a substantial 
amount of trade flows that die and then re-occur), the median duration of trade is still only one year, and the mean values are very similar to those for the benchmark data with multiple spells.

Third, if we use gap-adjusted spells, i.e. spells where all one-year or two-year exits from the market are disregarded, the median spell length is still only one year, even though the mean, of course, increases. In fact, the median does not increase to two years until we disregard even three-year absences. Fourth, in a related analysis we investigate whether the cut-off levels below which trade is not reported affect the observed duration of trade relationships. Trade flows that are close to the cut-off level might seem to be short-lived because they happen to fall just below the cut-off in one year - and hence are not reported while they are slightly larger the next year and are therefore observed in the trade statistics. To check whether this could be an explanation for the short duration of trade, we change the cut-off levels so that only observations with initial trade values above 1 million USD, 5 million USD, or 10 million USD are included. Interestingly, the median length of a spell is still one year, and the means are very similar to the benchmark case.

Fifth, the level of aggregation at which trade is reported would seem to have an obvious impact on the duration of trade. The higher the level of aggregation, the fewer exits from the market one would expect to see. Surprisingly and very interestingly, however, aggregating the data to the 3-, 2-, or 1-digit levels, thereby decreasing the number of product categories, changes the statistics only to a small extent. It is rather striking that even at the 1-digit level, where only ten product categories exist, the median duration of imports is still only two years, while the mean is 5.1 years. In other words, contrary to what one would expect, the level of aggregation is not very important, and even at a highly aggregated level, trade is very short-lived. While Besedeš and Prusa (2006a) draw the same surprising conclusion for US imports, we again note that EU trade is actually even more short-lived as the median duration of 1-digit (SITC) imports to the US is five or ten years (depending on the time period under study).

In Figures 1(a)-(d), we reiterate the same robustness checks by looking at the empirical survivor functions. The most important lesson herein is that our previous conclusions still seem to hold. EU imports remain very short-lived, and changes to the definition of spells, measurements of trade, or the level of aggregation do not alter this conclusion.

Having confirmed the robustness of the finding that EU imports are very short-lived, we next attempt to decipher if any other interesting patterns can be found in the data. We begin by noting that the period under study in this paper is 1962-2006, i.e. a period of well over 40 years. Having access to such a long time period is unprecedented in the trade duration literature, and makes it possible to see whether the duration of trade seems to change over time. Figure 2(a) illustrates that the fractions of spells that survive the first and fifth year of service do not really change over time but seem to fluctuate around roughly 40 and 15 percent, respectively. There are certainly many short term fluctuations 
from one year to another (suggesting that it is highly advisable to control for calendar time when running regressions), but the overall conclusion is nevertheless that the duration of trade does not change much across decades.

Figure 2: Variations in Trade Survival

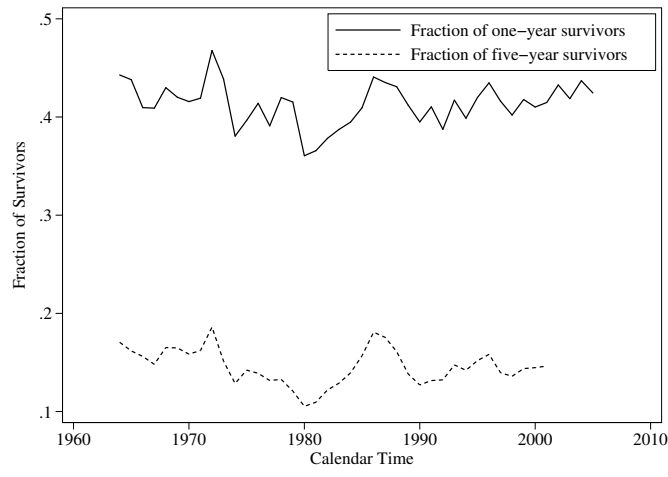

(a) The duration of trade over calender time

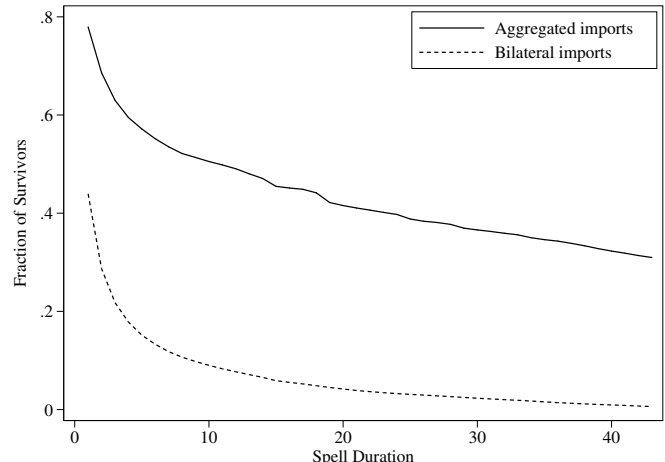

(b) Dying trade flows or switching partners?

Another way to search for insights into the explanations behind the short trade durations is to compare the descriptive statistics for bilateral trade flows with those for an importer's aggregated trade with the rest of the world. In Figure 2(b) we plot the fraction of surviving trade spells for both bilateral imports and data where, for every product, each importer's imports from the rest of the world have been aggregated. ${ }^{8}$ As Figure 2(b) illustrates, when import flows are aggregated over all exporters, slightly more than 20 percent of all spells only last for at most one year. Using bilateral data instead, this figure increases to just over 50 percent. Correspondingly, after ten years approximately 50 percent of the aggregated import spells have ceased compared to around 90 percent of the bilateral import spells. Overall, these figures suggest that there are at least two processes behind the short trade durations. First, the fact that it is not just bilateral but also aggregated import flows that die quickly implies that countries altogether stop importing many products soon after having started. Second, the fact that bilateral import flows have an even shorter duration than aggregated import flows strongly suggests that when a bilateral trade relationship stops, the importer in many instances has simply switched suppliers rather than ceased all imports of the product. To the best of our knowledge, the difference between these two processes has not yet been discussed in the literature on trade durations, even though it is potentially important because policy decisions could differ substantially based on the results.

\footnotetext{
${ }^{8}$ For this analysis to be meaningful, we must temporarily expand our sample of exporters to include all countries (i.e also the otherwise excluded EU countries themselves and former Soviet republics and South East European transition economies) as possible trading partners.
} 
Another way to make use of the information available in the data is to investigate whether the degree of trade diversification is correlated with the duration of trade. Figure 3 plots fractions of surviving spells at various spell lengths where the observed spells have been divided (based on different criteria) into three sets of roughly equal size. In Panel (a), the observed spells have been divided according to the number of products that the importer purchased at the international market at the beginning of the spell. Although the differences are small, we find that spells where the importer buys relatively few other products at the beginning of the spell have somewhat higher fractions of survivors than spells where the importer purchases many products. Similarly, Panel (b) shows an analysis of an investigation into whether the number of countries that a given importer buys a certain product from at the beginning of a spell is correlated with the duration of trade. Here, we again find very small differences, particularly for the first few years. Thus, while we know from the data that the importers diversify their imports over time both by adding new products and by adding new suppliers, we do not find any strong reasons to believe that this would affect the duration of trade. ${ }^{9}$

A different pattern is found when we focus on the exporters' trade characteristics. In Figures 3(c) and (d), the spells are divided based on the number of exported products and the number of export markets. Panel (c) suggests that there is indeed a connection between the number of exported products (to any market) and the duration of trade. Export spells where the exporting country is shipping many other products at the beginning of the spell are much less likely to die than export spells where the exporter is shipping only a few products. For example, about 50 percent of spells where the country exported more than 400 products survive the first year of service, while only about 30 percent of the spells where the country exported less than 200 products survive. ${ }^{10}$ In addition to this, Panel (d) illustrates a link between the number of EU markets that a given product is exported to at the beginning of the spell and the duration of trade. Clearly, export spells where the exporting country serves more than two other markets with the same product at the beginning of the spell survive to a much larger extent than export spells where

\footnotetext{
${ }^{9}$ Both the importing EU countries and the exporters in the rest of the world diversify their trade quite substantially over the studied time period, by trading new products and by entering new markets. Figures illustrating this development over time are available upon request. While we, in the interest of brevity, have chosen to only look at diversification from the importers' and the exporters' perspective, it is important to remember that exports (and imports) will also be diversified as soon as new trade relationships are formed. For example, countries starting to ship an "old" product to a country with which they already trade other products, but not this particular one, is also a type of diversification.

${ }^{10} \mathrm{We}$ want to make clear that we do not intend any strict causal interpretation here. It is for instance possible that large economies export many products and at the same time have long export spells, which would explain the pattern found in Figure 3(c). It is, on the other hand, also possible that firms in countries that export many products have access to more information about foreign markets which could facilitate exporting activities. The regression analysis below, where many factors can be controlled for at once, is a better tool for testing these hypotheses.
} 
Figure 3: Trade Diversification and Trade Duration

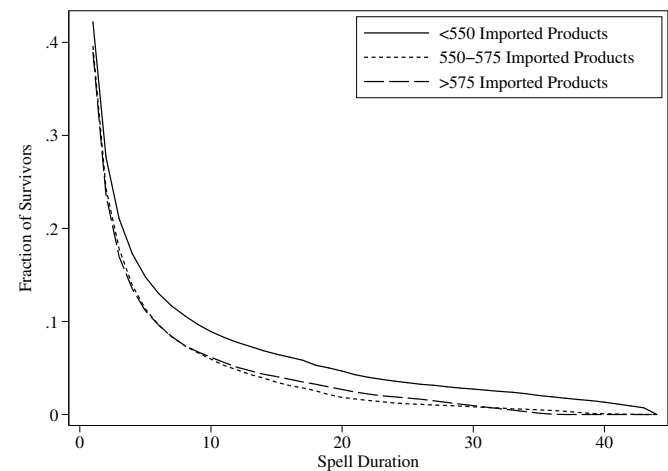

(a) Fraction of surviving spells depending on the number of imported products

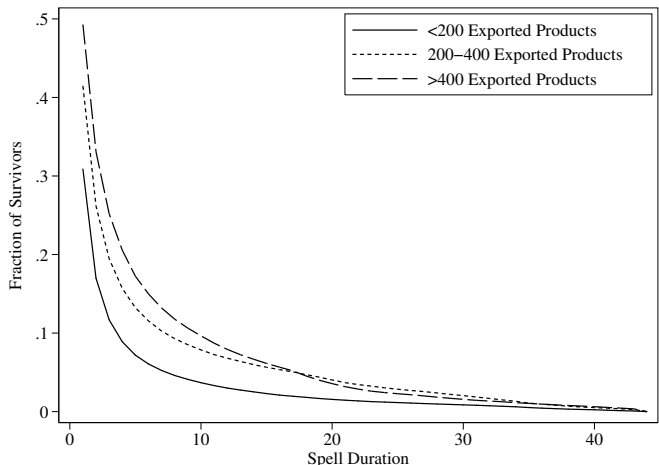

(c) Fraction of surviving spells depending on the number of exported products

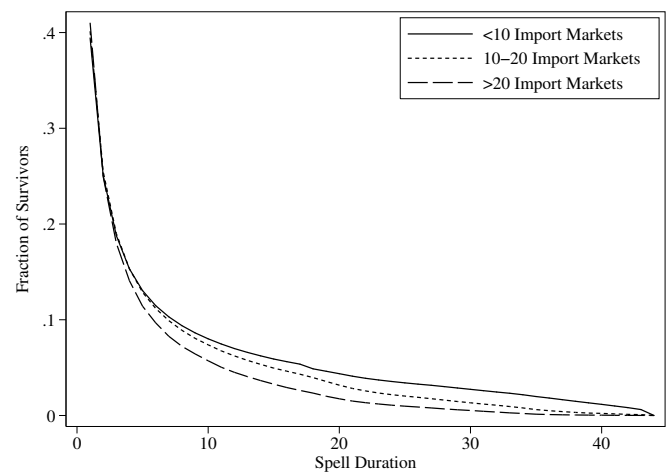

(b) Fraction of surviving spells depending on the number of supplying countries for a given product

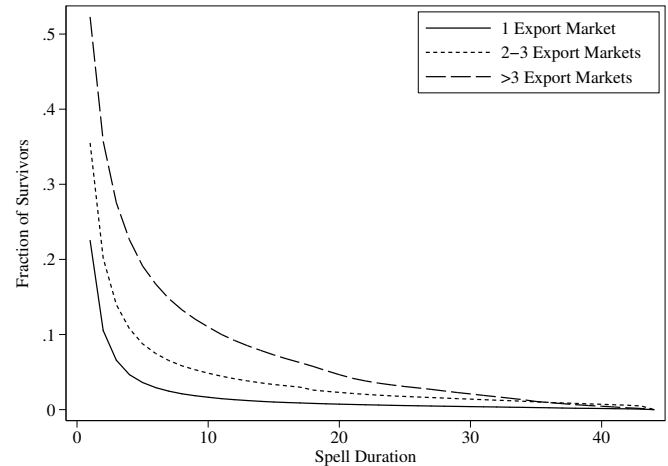

(d) Fraction of surviving spells depending on the number of export markets for a given product

the exporting country does not ship the product to any other market. For the first year of service the difference is very large indeed: about 30 percentage points. We therefore conclude that from a purely descriptive perspective - at least within the data set used the level of diversification in the exporter's trade seems to be influential when it comes to the duration of trade; while the importer's level of trade diversification seems to matter much less. ${ }^{11}$

To summarize this purely descriptive analysis, we find that EU imports are very shortlived: the median duration of imports is merely one year. Only 40 percent of all spells survive the first year of service, and less than ten percent of all relationships survive the first ten years. Compared with what has been found for, for example, US and German imports in the limited empirical literature, EU imports seem to be even more short-lived. Our results are not sensitive to changing the definition of a trade spell, using higher cut-off

\footnotetext{
${ }^{11}$ This could partly be the result of the importers in our data set being a more homogeneous group of countries when it comes to trade.
} 
levels for measuring trade, or even to employing different levels of product aggregation. In addition to these findings, we also notice several other interesting empirical patterns. First, the duration of trade does not exhibit any long-term upward or downward trend, but remains remarkably stable across the long time period that we study. Second, the short trade durations which have been found in the literature are the result of at least two processes: on the one hand countries shifting between different suppliers but continuing to import a given product, and on the other hand countries ceasing to import the product altogether. Third, short trade durations are empirically correlated with a lack of export diversification, both in terms of the number of other products the exporter ships and the number of import markets it serves with the given product. No clear evidence is found to connect the level of import diversification to trade durations.

\section{$5 \quad$ Regression Analysis}

\section{$5.1 \quad$ Methodology}

The duration of bilateral trade relationships is an emerging object of analysis in the economics literature. In the few articles existing so far, duration times are analyzed either in a purely descriptive manner by means of nonparametric survival estimates as proposed by Kaplan and Meier (1958), or in a regression context using continuous-time hazard models as proposed by Cox (1972). However, as pointed out by Hess and Persson (2010), there are several reasons why it is inappropriate to apply the Cox model when analyzing determinants of trade durations. First, the large number of short-lived trade relations combined with the fact that trade is only observed once every year results in a sizeable fraction of tied survival times. The Cox model faces difficulties in the presence of heavy ties, leading to biased coefficient estimates and standard errors (see e.g. Kalbfleisch and Prentice, 1980, or Cox and Oakes, 1984). Second, with data sets as large as those typically found in trade duration studies, it is very difficult to properly control for unobserved heterogeneity. Incorrectly neglecting unobserved heterogeneity (also known as frailty in the biostatistics literature) causes spurious negative duration dependence of the estimated hazard function as well as parameter bias (see e.g. van den Berg, 2001). Third, the Cox model imposes the restrictive and empirically questionable assumption of proportional hazards.

As a more appropriate alternative to the Cox model, Hess and Persson (2010) proposes the use of discrete-time duration models. Such models do not have difficulty in dealing with ties. Moreover, unobserved heterogeneity can easily be controlled for, and one does not have to assume proportional hazards, even though it is possible to do so. In addition, these models can be estimated using conventional regression techniques for binary response panel data (see e.g. Jenkins, 1995). While it can be shown that a stacked binary choice model employing a complementary log-log (cloglog) link function represents the exact groupedduration analogue of the Cox proportional hazards model, the more familiar logit and 
probit specifications do not imply the proportional hazards assumption (see e.g. Sueyoshi, 1995). Each of these models shares the virtues of the Cox model to allow for right censoring and a nonparametric estimation of the baseline hazard function.

By replicating an influential study by Besedeš and Prusa (2006b), but employing discretetime models as well as the original Cox model, Hess and Persson (2010) find empirical support for each of the discussed arguments against the Cox model, and conclude that using discrete-time models is a more appropriate choice. Following Hess and Persson (2010), we therefore focus on discrete-time duration models in our empirical analysis.

\subsection{Model Specification and Estimation Results}

We choose to formulate a parsimonious baseline specification of explanatory variables which in many ways resembles that found in other papers on the duration of trade. However, since we, unlike, for example, Besedeš and Prusa (2006a,b) and Nitsch (2009), have both importer and exporter variation, we are able to control for both importer and exporter characteristics. Based on the findings in the descriptive analysis, we also include some variables in our analysis that have not previously been used. Table A.2 in the Appendix provides an overview of all variables and data sources.

We estimate the baseline specification using discrete-time probit, logit, and cloglog models, specifying the baseline hazard in the most flexible possible fashion by means of dummy variables that enable the estimation of period-specific intercepts. This, in turn, allows for unrestricted period-specific changes in the estimated hazard rates. All leftcensored observations, which, if included, could lead to a misestimation of the hazard rate, are excluded. Besides using different hazard models, we present results from models with and without frailty, i.e. with and without random effects for every exporter-product combination. The results from the estimations can be found in Table 2 .

The baseline specification of explanatory variables is discussed below. First, however, a few words on how to choose between the presented estimation models. In general, the coefficients are similar for the various estimation procedures. To choose between models with and without frailty, we note that the likelihood-ratio tests strongly reject the null hypothesis of no latent heterogeneity for all model specifications. Hence, it is not surprising that accounting for unobserved heterogeneity substantially increases the respective loglikelihood values. The relative importance of unobserved heterogeneity for the different model specifications is indicated by the estimates for $\rho$ given in Table 2. Somewhat loosely, $\rho$ can be interpreted as the fraction of individual variation in the hazard rate that is due to variation in the unobserved factors. As the results in Table 2 indicate, unobserved heterogeneity plays a significant role in all model specifications and should thus not be ignored. Focusing on the models with frailty, we obtain the largest log-likelihood value from the probit model, and the smallest from the cloglog model. This is not surprising, since the cloglog specification imposes the restrictive assumption of proportional hazards 
Table 2: Estimation Results

\begin{tabular}{|c|c|c|c|c|c|c|}
\hline & \multicolumn{3}{|c|}{ Models without frailty } & \multicolumn{3}{|c|}{ Models with frailty } \\
\hline & Probit & Logit & Cloglog & Probit & Logit & Cloglog \\
\hline Log distance & $\begin{array}{r}-0.0077 \\
(0.000)\end{array}$ & $\begin{array}{r}-0.0133 \\
(0.000)\end{array}$ & $\begin{array}{r}-0.0078 \\
(0.000)\end{array}$ & $\begin{array}{r}0.0396 \\
(0.000)\end{array}$ & $\begin{array}{c}0.0593 \\
(0.000)\end{array}$ & $\begin{array}{c}0.0313 \\
(0.000)\end{array}$ \\
\hline Common language & $\begin{array}{r}-0.1496 \\
(0.000)\end{array}$ & $\begin{array}{r}-0.2545 \\
(0.000)\end{array}$ & $\begin{array}{r}-0.1783 \\
(0.000)\end{array}$ & $\begin{array}{r}-0.1890 \\
(0.000)\end{array}$ & $\begin{array}{r}-0.3180 \\
(0.000)\end{array}$ & $\begin{array}{r}-0.2163 \\
(0.000)\end{array}$ \\
\hline Colonial history & $\begin{array}{r}-0.1001 \\
(0.000)\end{array}$ & $\begin{array}{r}-0.1618 \\
(0.000)\end{array}$ & $\begin{array}{r}-0.1138 \\
(0.000)\end{array}$ & $\begin{array}{r}-0.1032 \\
(0.000)\end{array}$ & $\begin{array}{r}-0.1699 \\
(0.000)\end{array}$ & $\begin{array}{r}-0.1156 \\
(0.000)\end{array}$ \\
\hline $\begin{array}{l}\text { Log GDP } \\
\text { (importer) }\end{array}$ & $\begin{array}{r}-0.2949 \\
(0.000)\end{array}$ & $\begin{array}{r}-0.5191 \\
(0.000)\end{array}$ & $\begin{array}{r}-0.3733 \\
(0.000)\end{array}$ & $\begin{array}{r}-0.2858 \\
(0.000)\end{array}$ & $\begin{array}{r}-0.5020 \\
(0.000)\end{array}$ & $\begin{array}{r}-0.3626 \\
(0.000)\end{array}$ \\
\hline $\begin{array}{l}\text { Log GDP } \\
\text { (exporter) }\end{array}$ & $\begin{array}{r}0.0138 \\
(0.000)\end{array}$ & $\begin{array}{r}0.0208 \\
(0.000)\end{array}$ & $\begin{array}{r}0.0110 \\
(0.000)\end{array}$ & $\begin{array}{r}0.0085 \\
(0.000)\end{array}$ & $\begin{array}{r}0.0132 \\
(0.000)\end{array}$ & $\begin{array}{r}0.0083 \\
(0.000)\end{array}$ \\
\hline Exporter LDC & $\begin{array}{r}-0.0201 \\
(0.000)\end{array}$ & $\begin{array}{r}-0.0356 \\
(0.000)\end{array}$ & $\begin{array}{r}-0.0277 \\
(0.000)\end{array}$ & $\begin{array}{r}-0.0572 \\
(0.000)\end{array}$ & $\begin{array}{r}-0.0942 \\
(0.000)\end{array}$ & $\begin{array}{r}-0.0558 \\
(0.000)\end{array}$ \\
\hline $\begin{array}{l}\text { Log number of } \\
\text { export products }\end{array}$ & $\begin{array}{r}-0.1145 \\
(0.000)\end{array}$ & $\begin{array}{r}-0.1800 \\
(0.000)\end{array}$ & $\begin{array}{r}-0.1129 \\
(0.000)\end{array}$ & $\begin{array}{r}-0.2294 \\
(0.000)\end{array}$ & $\begin{array}{r}-0.3642 \\
(0.000)\end{array}$ & $\begin{array}{r}-0.2149 \\
(0.000)\end{array}$ \\
\hline $\begin{array}{l}\text { Number of } \\
\text { export markets }\end{array}$ & $\begin{array}{r}-0.1042 \\
(0.000)\end{array}$ & $\begin{array}{r}-0.1780 \\
(0.000)\end{array}$ & $\begin{array}{r}-0.1338 \\
(0.000)\end{array}$ & $\begin{array}{r}-0.0885 \\
(0.000)\end{array}$ & $\begin{array}{r}-0.1531 \\
(0.000)\end{array}$ & $\begin{array}{r}-0.1184 \\
(0.000)\end{array}$ \\
\hline Lagged duration & $\begin{array}{r}-0.0183 \\
(0.000)\end{array}$ & $\begin{array}{r}-0.0363 \\
(0.000)\end{array}$ & $\begin{array}{r}-0.0334 \\
(0.000)\end{array}$ & $\begin{array}{r}-0.0188 \\
(0.000)\end{array}$ & $\begin{array}{r}-0.0358 \\
(0.000)\end{array}$ & $\begin{array}{r}-0.0319 \\
(0.000)\end{array}$ \\
\hline $\begin{array}{l}\text { Log initial } \\
\text { import value }\end{array}$ & $\begin{array}{r}-0.0637 \\
(0.000)\end{array}$ & $\begin{array}{r}-0.1144 \\
(0.000)\end{array}$ & $\begin{array}{r}-0.0861 \\
(0.000)\end{array}$ & $\begin{array}{r}-0.0760 \\
(0.000)\end{array}$ & $\begin{array}{r}-0.1351 \\
(0.000)\end{array}$ & $\begin{array}{r}-0.0986 \\
(0.000)\end{array}$ \\
\hline $\begin{array}{l}\text { Differentiated } \\
\text { product }\end{array}$ & $\begin{array}{r}-0.0769 \\
(0.000)\end{array}$ & $\begin{array}{r}-0.1338 \\
(0.000)\end{array}$ & $\begin{array}{r}-0.0899 \\
(0.000)\end{array}$ & $\begin{array}{r}-0.1095 \\
(0.000)\end{array}$ & $\begin{array}{r}-0.1890 \\
(0.000)\end{array}$ & $\begin{array}{r}-0.1254 \\
(0.000)\end{array}$ \\
\hline $\begin{array}{l}\text { Log total } \\
\text { import value }\end{array}$ & $\begin{array}{r}-0.0018 \\
(0.008)\end{array}$ & $\begin{array}{r}-0.0008 \\
(0.485)\end{array}$ & $\begin{array}{r}0.0014 \\
(0.110)\end{array}$ & $\begin{array}{r}-0.0198 \\
(0.000)\end{array}$ & $\begin{array}{r}-0.0298 \\
(0.000)\end{array}$ & $\begin{array}{r}-0.0155 \\
(0.000)\end{array}$ \\
\hline EU member & $\begin{array}{r}-0.0465 \\
(0.000)\end{array}$ & $\begin{array}{r}-0.0804 \\
(0.000)\end{array}$ & $\begin{array}{r}-0.0562 \\
(0.000)\end{array}$ & $\begin{array}{r}-0.0427 \\
(0.000)\end{array}$ & $\begin{array}{r}-0.0757 \\
(0.000)\end{array}$ & $\begin{array}{r}-0.0581 \\
(0.000)\end{array}$ \\
\hline $\begin{array}{l}\Delta \text { log relative } \\
\text { real exchange rate }\end{array}$ & $\begin{array}{r}0.0707 \\
(0.000)\end{array}$ & $\begin{array}{r}0.1185 \\
(0.000)\end{array}$ & $\begin{array}{r}0.0719 \\
(0.000)\end{array}$ & $\begin{array}{r}0.0675 \\
(0.000)\end{array}$ & $\begin{array}{r}0.1130 \\
(0.000)\end{array}$ & $\begin{array}{r}0.0679 \\
(0.000)\end{array}$ \\
\hline Duration dummies & yes & yes & yes & yes & yes & yes \\
\hline Year dummies & yes & yes & yes & yes & yes & yes \\
\hline Importer dummies & yes & yes & yes & yes & yes & yes \\
\hline Spell no. dummies & yes & yes & yes & yes & yes & yes \\
\hline$\rho$ & & & & $\begin{array}{r}0.0561 \\
(0.000)\end{array}$ & $\begin{array}{r}0.0473 \\
(0.000)\end{array}$ & $\begin{array}{r}0.0417 \\
(0.000)\end{array}$ \\
\hline Observations & 2220871 & 2220871 & 2220871 & 2220871 & 2220871 & 2220871 \\
\hline Spells & 692148 & 692148 & 692148 & 692148 & 692148 & 692148 \\
\hline Trade relations & 265396 & 265396 & 265396 & 265396 & 265396 & 265396 \\
\hline Log likelihood & -901836 & -901418 & -901037 & -895709 & -895936 & -896784 \\
\hline
\end{tabular}

Note: $P$-values in parentheses. Models with frailty include exporter-product random effects. $\rho$ denotes the fraction of the error variance that is due to variation in the unobserved individual factors. A trade relation is defined as an importer-exporter-product combination. The number of observations is given by the total number of years with positive trade for all trade relationships. 
which we could reject for the data at hand by applying a formal test procedure proposed by McCall (1994). In summary, as the results indicate that the probit model with frailty best fits the data at hand, we will focus on this model specification when discussing the estimation results.

In the trade literature, two countries with a short distance between them or which share the same language or a joint colonial history are often expected to have lower costs for trading. It seems reasonable to assume that, everything else being equal, higher trade costs should make a trading relationship more vulnerable to negative shocks and increase the likelihood of failure. Therefore we would expect distance to increase the hazard, while a common language and a joint colonial history ought to lower the hazard. To control for these factors we include the logarithm of the distance between the trading countries' capitals and dummy variables that take the value of one if the two trading partners share the same language or have a colonial relationship, and zero otherwise. Concentrating on our preferred random-effects probit model, the estimated parameters support these hypotheses: distance has a significantly positive coefficient, while the coefficients for common language and colonial history are both significantly negative. ${ }^{12}$ Note though that in this case, it actually matters substantially whether or not we control for unobserved heterogeneity: the coefficient for distance is significantly negative in all models when we do not include random effects.

Further, the importer's GDP is included as a proxy for import demand, while the corresponding variable is included for the exporter to control for export supply capacity. We expect that higher import demand or export supply capacity will lower the hazard. This hypothesis is partly supported by the results: the importer's GDP has a significantly negative coefficient. However, the exporter's GDP has a positive and significant coefficient, which would suggest that trading relationships involving economically large exporters are more likely to die. This unexpected result is not particularly robust, though. As discussed in Section 5.3, if we drop trade data from the 1960s (or aggregate the data), the exporter's GDP has a significantly negative effect on the hazard.

The level of development in the exporting country could be another factor which influences the hazard of trade flows dying. It is, for example, generally expected that countries at different development stages do not produce and export the same kinds of goods, and the level of development is also strongly correlated with the quality of trade-promoting institutions. To control for such effects we include a dummy variable which takes the value one if the exporter is formally recognized as a least developed country (LDC) by the

\footnotetext{
${ }^{12}$ To also establish an understanding of the size of these effects, consider the common-language variable with a coefficient value of -0.189 : if all other covariates are fixed at their means, this value implies that the first-year hazard for a trade relationship between two countries with a common language is about seven percentage points lower than the corresponding hazard for countries that do not share a common language (38\% vs. $45 \%)$.
} 
United Nations. ${ }^{13}$ Somewhat surprisingly, this variable has a significantly negative coefficient, suggesting that LDCs' export flows are longer-lasting than export flows from more developed countries. We are not sure how to interpret this result, but note that Nitsch (2009) finds a positive coefficient for the exporter's GDP per capita, and the interpretation of that - namely that richer exporters would face a higher hazard - is consistent with our negative LDC-effect. This is an issue where further research is needed.

Based on our findings in the descriptive analysis, we also include controls for the number of exported products and the number of export markets. The effects of these variables are both significantly negative: exporting many products and/or to many export markets has a negative effect on the probability that an export spell dies. The interpretation we make is that countries with a generally diversified export structure will stand a better chance to export a given product for long periods of time. A possible mechanism for this effect could be that firms in countries that export many products or trade with many other countries have access to more information about how to do business in foreign markets, which would facilitate exporting activities. For instance, Greenaway and Kneller (2008) find evidence that agglomeration raises the probability of export market entry for UK manufacturing firms, and discuss that this may be due to information or technological spillovers. If this is the case, these spillovers may reasonably improve firms' post-entry productivity as well, which would imply that the existence of many other export firms would decrease the likelihood of failure. ${ }^{14}$

Related to this, as discussed in the firm-level literature, exporting may in itself have a positive effect on firms' performance as firms may learn by exporting. ${ }^{15}$ As past export performance could therefore be an indicator of the level of knowledge, we include the lagged duration, i.e. the number of years that a preceding export spell lasted, to control for such effects. This may capture learning effects, but could also be an indicator of the competitiveness of the exporter in the given sector: if past export spells have lasted for a long time, this suggests that the current likelihood of failure is smaller. This notion finds support in the results with longer-lasting past export spells making it less likely that the current export spell will die.

Based on the theoretical predictions in Rauch and Watson (2003), who model developed countries' search for developing country suppliers, Besedeš and Prusa (2006b) find empirical

\footnotetext{
${ }^{13}$ An alternative could be to include the level of per capita GDP, but the LDC dummy has the advantage of being based on a broader view of development which also takes various issues connected with economic vulnerability and human capital into account.

${ }^{14}$ Nitsch (2009) includes some similar variables when studying German imports: the number of imported products from a given supplier and the number of countries exporting the same product to Germany. Using our terminology, he therefore controls for import diversification, while we - on the basis of our findings in the descriptive analysis - control for export diversification.

${ }^{15}$ See e.g. Clerides et al. (1998) for a discussion. Wagner (2007) and Greenaway and Kneller (2007) offer overviews of the literature, and Martins and Yang (2009) conduct a meta-analysis of more than 30 empirical studies.
} 
evidence that trade relationships that either start with a large initial transaction or involve differentiated goods will have a smaller likelihood of dying. Our results confirm these findings: a dummy indicating whether or not the product is differentiated has a negative and significant coefficient, as does the logarithm of the initial value of imports. In our set of explanatory variables, we also include the total value of EU imports for each product and year. The hypothesis is that a higher value of total EU imports (i.e. a larger EU market) reduces the hazard that a given trade relationship dies. As expected, the estimated coefficient is negative and significant.

Further, we include a dummy for EU membership to control for whether or not the importer has become an EU-country. This variable has a negative and significant coefficient, suggesting that EU membership lowers the hazard of failure. We also include the yearly difference in (the $\log$ of) the relative real exchange rate, since exchange rate movements could explain exits from (and entry into) the market. This variable has a significant and positive coefficient, suggesting that an appreciation of the exporter's currency relative to the currencies of competing exporters, as expected, increases the likelihood of failure.

Our random effects control for all unobserved heterogeneity that is constant within exporter-product combinations. However, as this may not be the only type of unobserved heterogeneity, we also include a large set of dummy variables. First, since we study a very long time period, it is possible that the duration of exports to the $\mathrm{EU}$ varies over time for reasons other than those we explicitly control for. We therefore include calendar year dummies to control for all such latent factors that are common to all country pairs and products in a given year, but vary over time. Second, we include importer dummies to capture structural differences between importing countries. Third, since our estimation methods assume that all spells are independent conditional on the covariates, we include dummy variables capturing the number of previous spells for any given trade relationship. ${ }^{16}$

\subsection{Robustness Analysis}

As reported in Table 2, there are few qualitative differences between the results from the probit, logit, and cloglog estimations. While the coefficient for distance, as mentioned above, changes signs when unobserved heterogeneity is controlled for, the only other variable that is qualitatively affected by the choice of estimation model is the total import value. In the models without frailty, this variable is insignificant using a logit or cloglog model. In all models which include random effects, however, the variable is significantly negative. This suggests that the biases arising when unobserved heterogeneity is not prop-

\footnotetext{
${ }^{16}$ The economic meaning of such dummies capturing first, second, third spells, etc. is sometimes discussed in the literature. We want to point out that this is not really appropriate here, because even though a specific spell may be the first observed one in the data, there is no way of telling whether or not two countries have traded a particular product prior to the first year of the observation period. Thus, an observed "first" spell may actually be of a much higher order, rendering interpretation quite difficult.
} 
erly controlled for (see Hess and Persson, 2010, for a discussion) are indeed an important issue in empirical studies on the duration of trade.

Focusing henceforth on our preferred model - the probit model with random effects at the exporter-product level - we perform further robustness checks. Following the same procedure as in the descriptive analysis above, we sequentially change the definition of a spell and use single spells, first spells, and gap-adjusted spells. In the latter, however, we forego the inclusion of three-year and two-year gaps and consider only gaps of one year. As shown in Table 3, while the former two modifications strongly reduce the number of observations, the results are largely unaffected. The only exceptions are: the distance no longer being significant at the 1-percent level when using single spells; and the total import value becoming insignificant in the estimation using first spells.

Further, we try an alternative way to control for unobserved heterogeneity. A randomeffects specification assumes that the unobserved individual-specific effects are uncorrelated with the observed regressors. To make sure that our results are not overly sensitive to this assumption, we re-estimate the benchmark data using a fixed-effects logit model. While noting that this makes it impossible to estimate parameters for the differentiated-good and the LDC variable, the results are otherwise largely unaltered. The lone exception is that the unexpected positive coefficient that we found for the exporter's GDP in the baseline estimations is now replaced with a significantly negative coefficient. ${ }^{17}$

Since we study an extended time period (1962-2006), we also consider the possibility that the effects of various factors on the probability that a trade relationship dies vary considerably over time. Therefore, we successively exclude years at the beginning of the observation period, and estimate the model for the time periods beginning in 1970, 1980, and 1990, respectively. As displayed in Table 4, there is only one qualitative difference to the baseline results. The unexpected positive coefficient for the exporter's GDP is replaced by significantly negative coefficients as soon as we disregard data from the 1960s. Since it seems reasonable to assume that the quality of GDP data could be particularly poor for many developing countries in such an early observation period, this is a reassuring sign of robustness. To conclude, the time period under study does not seem to matter for the effects of the explanatory variables on the hazard rate.

Lastly, we also investigate whether the level of aggregation for the trade data matters for the results. We therefore re-estimate the model by aggregating the data at the 3-, 2-, and 1-digit SITC levels. Consistent with what we observed in the descriptive analysis, this has far smaller effects than one would expect. As was the case when we disregarded data from the 1960s, the exporter's GDP again obtains the expected significantly negative

\footnotetext{
${ }^{17}$ We have attempted a Hausman test to evaluate the appropriateness of a random-effects logit model versus a fixed-effects logit model. However, since the difference between the estimated covariance matrices of the fixed-effects and the random-effects estimates was not a positive definite matrix, we were unable to perform the test. This outcome is fairly common in empirical applications.
} 
Table 3: Robustness Results: Spell Definition and Fixed Effects

\begin{tabular}{|c|c|c|c|c|}
\hline & Single spell & First spell & Gap-adjusted & FE logit \\
\hline Log distance & $\begin{array}{r}0.0167 \\
(0.030)\end{array}$ & $\begin{array}{r}0.0098 \\
(0.006)\end{array}$ & $\begin{array}{r}0.0463 \\
(0.000)\end{array}$ & $\begin{array}{r}0.5666 \\
(0.000)\end{array}$ \\
\hline Common language & $\begin{array}{r}-0.2522 \\
(0.000)\end{array}$ & $\begin{array}{r}-0.1849 \\
(0.000)\end{array}$ & $\begin{array}{r}-0.2045 \\
(0.000)\end{array}$ & $\begin{array}{r}-0.3246 \\
(0.000)\end{array}$ \\
\hline Colonial history & $\begin{array}{r}-0.1419 \\
(0.000)\end{array}$ & $\begin{array}{r}-0.1022 \\
(0.000)\end{array}$ & $\begin{array}{r}-0.1112 \\
(0.000)\end{array}$ & $\begin{array}{r}-0.2942 \\
(0.000)\end{array}$ \\
\hline $\begin{array}{l}\text { Log GDP } \\
\text { (importer) }\end{array}$ & $\begin{array}{r}-0.6196 \\
(0.000)\end{array}$ & $\begin{array}{r}-0.3607 \\
(0.000)\end{array}$ & $\begin{array}{r}-0.3110 \\
(0.000)\end{array}$ & $\begin{array}{r}-0.4957 \\
(0.000)\end{array}$ \\
\hline $\begin{array}{l}\text { Log GDP } \\
\text { (exporter) }\end{array}$ & $\begin{array}{r}0.0229 \\
(0.000)\end{array}$ & $\begin{array}{r}0.0105 \\
(0.000)\end{array}$ & $\begin{array}{r}0.0050 \\
(0.008)\end{array}$ & $\begin{array}{r}-0.0472 \\
(0.000)\end{array}$ \\
\hline Exporter LDC & $\begin{array}{r}-0.0728 \\
(0.000)\end{array}$ & $\begin{array}{r}-0.0370 \\
(0.000)\end{array}$ & $\begin{array}{r}-0.0568 \\
(0.000)\end{array}$ & \\
\hline $\begin{array}{l}\text { Log number of } \\
\text { export products }\end{array}$ & $\begin{array}{r}-0.4152 \\
(0.000)\end{array}$ & $\begin{array}{r}-0.1620 \\
(0.000)\end{array}$ & $\begin{array}{r}-0.2695 \\
(0.000)\end{array}$ & $\begin{array}{r}-0.6510 \\
(0.000)\end{array}$ \\
\hline $\begin{array}{l}\text { Number of } \\
\text { export markets }\end{array}$ & $\begin{array}{r}-0.1721 \\
(0.000)\end{array}$ & $\begin{array}{r}-0.1130 \\
(0.000)\end{array}$ & $\begin{array}{r}-0.0955 \\
(0.000)\end{array}$ & $\begin{array}{r}-0.0967 \\
(0.000)\end{array}$ \\
\hline Lagged duration & & & $\begin{array}{r}-0.0129 \\
(0.000)\end{array}$ & $\begin{array}{r}-0.0256 \\
(0.000)\end{array}$ \\
\hline $\begin{array}{l}\text { Log initial } \\
\text { import value }\end{array}$ & $\begin{array}{r}-0.0681 \\
(0.000)\end{array}$ & $\begin{array}{r}-0.0815 \\
(0.000)\end{array}$ & $\begin{array}{r}-0.0524 \\
(0.000)\end{array}$ & $\begin{array}{r}-0.1477 \\
(0.000)\end{array}$ \\
\hline $\begin{array}{l}\text { Differentiated } \\
\text { product }\end{array}$ & $\begin{array}{r}-0.1857 \\
(0.000)\end{array}$ & $\begin{array}{r}-0.0855 \\
(0.000)\end{array}$ & $\begin{array}{r}-0.1328 \\
(0.000)\end{array}$ & \\
\hline $\begin{array}{l}\text { Log total } \\
\text { import value }\end{array}$ & $\begin{array}{r}-0.0293 \\
(0.000)\end{array}$ & $\begin{array}{r}-0.0011 \\
(0.434)\end{array}$ & $\begin{array}{r}-0.0335 \\
(0.000)\end{array}$ & $\begin{array}{r}-0.1102 \\
(0.000)\end{array}$ \\
\hline EU member & $\begin{array}{r}-0.0876 \\
(0.000)\end{array}$ & $\begin{array}{r}-0.0375 \\
(0.000)\end{array}$ & $\begin{array}{r}-0.0532 \\
(0.000)\end{array}$ & $\begin{array}{r}-0.0830 \\
(0.000)\end{array}$ \\
\hline $\begin{array}{l}\Delta \text { log relative } \\
\text { real exchange rate }\end{array}$ & $\begin{array}{r}0.1421 \\
(0.000)\end{array}$ & $\begin{array}{r}0.0611 \\
(0.000)\end{array}$ & $\begin{array}{r}0.0639 \\
(0.000)\end{array}$ & $\begin{array}{r}0.1125 \\
(0.000)\end{array}$ \\
\hline Duration dummies & yes & yes & yes & yes \\
\hline Year dummies & yes & yes & yes & yes \\
\hline Importer dummies & yes & yes & yes & yes \\
\hline Spell no. dummies & no & no & yes & yes \\
\hline$\rho$ & $\begin{array}{r}0.1878 \\
(0.000)\end{array}$ & $\begin{array}{r}0.0471 \\
(0.000)\end{array}$ & $\begin{array}{r}0.0672 \\
(0.000)\end{array}$ & \\
\hline Observations & 452787 & 798789 & 2081923 & 2164415 \\
\hline Spells & 103489 & 265396 & 514313 & 658856 \\
\hline Trade relations & 103489 & 265396 & 257699 & 238534 \\
\hline Log likelihood & -86378 & -298167 & -725654 & -802601 \\
\hline
\end{tabular}

Note: $P$-values in parentheses. All models include random or fixed effects on the exporter-product level. Unless otherwise stated, the preferred random-effects probit model is estimated. $\rho$ denotes the fraction of the error variance that is due to variation in the unobserved individual factors. A trade relation is defined as an importer-exporter-product combination. The number of observations is given by the total number of years with positive trade for all trade relationships. 
Table 4: Robustness Results: Time Period and Product Aggregation

\begin{tabular}{|c|c|c|c|c|c|c|}
\hline & 1970-2006 & 1980-2006 & 1990-2006 & 3-digit & 2-digit & 1-digit \\
\hline Log distance & $\begin{array}{r}0.0609 \\
(0.000)\end{array}$ & $\begin{array}{r}0.0607 \\
(0.000)\end{array}$ & $\begin{array}{r}0.0493 \\
(0.000)\end{array}$ & $\begin{array}{r}0.0518 \\
(0.000)\end{array}$ & $\begin{array}{r}0.0635 \\
(0.000)\end{array}$ & $\begin{array}{r}0.0566 \\
(0.000)\end{array}$ \\
\hline Common language & $\begin{array}{r}-0.1701 \\
(0.000)\end{array}$ & $\begin{array}{r}-0.1813 \\
(0.000)\end{array}$ & $\begin{array}{r}-0.1924 \\
(0.000)\end{array}$ & $\begin{array}{r}-0.2080 \\
(0.000)\end{array}$ & $\begin{array}{r}-0.2162 \\
(0.000)\end{array}$ & $\begin{array}{r}-0.2030 \\
(0.000)\end{array}$ \\
\hline Colonial history & $\begin{array}{r}-0.1241 \\
(0.000)\end{array}$ & $\begin{array}{r}-0.1222 \\
(0.000)\end{array}$ & $\begin{array}{r}-0.0991 \\
(0.000)\end{array}$ & $\begin{array}{r}-0.1550 \\
(0.000)\end{array}$ & $\begin{array}{r}-0.1864 \\
(0.000)\end{array}$ & $\begin{array}{r}-0.2242 \\
(0.000)\end{array}$ \\
\hline $\begin{array}{l}\text { Log GDP } \\
\text { (importer) }\end{array}$ & $\begin{array}{r}-0.2833 \\
(0.000)\end{array}$ & $\begin{array}{r}-0.3360 \\
(0.000)\end{array}$ & $\begin{array}{r}-0.4202 \\
(0.000)\end{array}$ & $\begin{array}{r}-0.2989 \\
(0.000)\end{array}$ & $\begin{array}{r}-0.2944 \\
(0.000)\end{array}$ & $\begin{array}{r}-0.3507 \\
(0.000)\end{array}$ \\
\hline $\begin{array}{l}\text { Log GDP } \\
\text { (exporter) }\end{array}$ & $\begin{array}{r}-0.0179 \\
(0.000)\end{array}$ & $\begin{array}{r}-0.0347 \\
(0.000)\end{array}$ & $\begin{array}{r}-0.0672 \\
(0.000)\end{array}$ & $\begin{array}{r}-0.0098 \\
(0.000)\end{array}$ & $\begin{array}{r}-0.0273 \\
(0.000)\end{array}$ & $\begin{array}{r}-0.0583 \\
(0.000)\end{array}$ \\
\hline Exporter LDC & $\begin{array}{r}-0.0900 \\
(0.000)\end{array}$ & $\begin{array}{r}-0.0909 \\
(0.000)\end{array}$ & $\begin{array}{r}-0.0875 \\
(0.000)\end{array}$ & $\begin{array}{r}-0.0326 \\
(0.000)\end{array}$ & $\begin{array}{r}-0.0062 \\
(0.570)\end{array}$ & $\begin{array}{r}0.0412 \\
(0.057)\end{array}$ \\
\hline $\begin{array}{l}\text { Log number of } \\
\text { export products }\end{array}$ & $\begin{array}{r}-0.2845 \\
(0.000)\end{array}$ & $\begin{array}{r}-0.2906 \\
(0.000)\end{array}$ & $\begin{array}{r}-0.2269 \\
(0.000)\end{array}$ & $\begin{array}{r}-0.2373 \\
(0.000)\end{array}$ & $\begin{array}{r}-0.1728 \\
(0.000)\end{array}$ & $\begin{array}{r}-0.0279 \\
(0.617)\end{array}$ \\
\hline $\begin{array}{l}\text { Number of } \\
\text { export markets }\end{array}$ & $\begin{array}{r}-0.0772 \\
(0.000)\end{array}$ & $\begin{array}{r}-0.0679 \\
(0.000)\end{array}$ & $\begin{array}{r}-0.0511 \\
(0.000)\end{array}$ & $\begin{array}{r}-0.0944 \\
(0.000)\end{array}$ & $\begin{array}{r}-0.0987 \\
(0.000)\end{array}$ & $\begin{array}{r}-0.0951 \\
(0.000)\end{array}$ \\
\hline Lagged duration & $\begin{array}{r}-0.0251 \\
(0.000)\end{array}$ & $\begin{array}{r}-0.0328 \\
(0.000)\end{array}$ & $\begin{array}{r}-0.0521 \\
(0.000)\end{array}$ & $\begin{array}{r}-0.0205 \\
(0.000)\end{array}$ & $\begin{array}{r}-0.0201 \\
(0.000)\end{array}$ & $\begin{array}{r}-0.0209 \\
(0.000)\end{array}$ \\
\hline $\begin{array}{l}\text { Log initial } \\
\text { import value }\end{array}$ & $\begin{array}{r}-0.0755 \\
(0.000)\end{array}$ & $\begin{array}{r}-0.0763 \\
(0.000)\end{array}$ & $\begin{array}{r}-0.0765 \\
(0.000)\end{array}$ & $\begin{array}{r}-0.0545 \\
(0.000)\end{array}$ & $\begin{array}{r}-0.0424 \\
(0.000)\end{array}$ & $\begin{array}{r}-0.0281 \\
(0.000)\end{array}$ \\
\hline $\begin{array}{l}\text { Differentiated } \\
\text { product }\end{array}$ & $\begin{array}{r}-0.1311 \\
(0.000)\end{array}$ & $\begin{array}{r}-0.1516 \\
(0.000)\end{array}$ & $\begin{array}{r}-0.1579 \\
(0.000)\end{array}$ & & & \\
\hline $\begin{array}{l}\text { Log total } \\
\text { import value }\end{array}$ & $\begin{array}{r}-0.0376 \\
(0.000)\end{array}$ & $\begin{array}{r}-0.0415 \\
(0.000)\end{array}$ & $\begin{array}{r}-0.0393 \\
(0.000)\end{array}$ & $\begin{array}{r}-0.0236 \\
(0.000)\end{array}$ & $\begin{array}{r}-0.0245 \\
(0.000)\end{array}$ & $\begin{array}{r}-0.0400 \\
(0.000)\end{array}$ \\
\hline EU member & $\begin{array}{r}-0.0436 \\
(0.000)\end{array}$ & $\begin{array}{r}-0.0741 \\
(0.000)\end{array}$ & $\begin{array}{r}-0.1387 \\
(0.000)\end{array}$ & $\begin{array}{r}-0.0467 \\
(0.000)\end{array}$ & $\begin{array}{r}-0.0575 \\
(0.000)\end{array}$ & $\begin{array}{r}-0.0613 \\
(0.000)\end{array}$ \\
\hline $\begin{array}{l}\Delta \text { log relative } \\
\text { real exchange rate }\end{array}$ & $\begin{array}{r}0.0736 \\
(0.000)\end{array}$ & $\begin{array}{r}0.1143 \\
(0.000)\end{array}$ & $\begin{array}{r}0.1192 \\
(0.000)\end{array}$ & $\begin{array}{r}0.0481 \\
(0.000)\end{array}$ & $\begin{array}{r}0.0346 \\
(0.000)\end{array}$ & $\begin{array}{r}0.0627 \\
(0.001)\end{array}$ \\
\hline Duration dummies & yes & yes & yes & yes & yes & yes \\
\hline Year dummies & yes & yes & yes & yes & yes & yes \\
\hline Importer dummies & yes & yes & yes & yes & yes & yes \\
\hline Spell no. dummies & yes & yes & yes & yes & yes & yes \\
\hline$\rho$ & $\begin{array}{r}0.0856 \\
(0.000)\end{array}$ & $\begin{array}{r}0.1052 \\
(0.000)\end{array}$ & $\begin{array}{r}0.1147 \\
(0.000)\end{array}$ & $\begin{array}{r}0.0499 \\
(0.000)\end{array}$ & $\begin{array}{r}0.0467 \\
(0.000)\end{array}$ & $\begin{array}{c}0.0513 \\
(0.000)\end{array}$ \\
\hline Observations & 1887638 & 1432718 & 895433 & 1268136 & 605949 & 154743 \\
\hline Spells & 640848 & 531054 & 381658 & 364285 & 156911 & 32146 \\
\hline Trade relations & 256058 & 236630 & 202567 & 130647 & 53545 & 10242 \\
\hline Log likelihood & -813386 & -651646 & -444489 & -487889 & -220701 & -49362 \\
\hline
\end{tabular}

Note: $P$-values in parentheses. In all cases, a probit model with random effects on the exporter-product level is estimated. $\rho$ denotes the fraction of the error variance that is due to variation in the unobserved individual factors. A trade relation is defined as an importer-exporter-product combination. The number of observations is given by the total number of years with positive trade for all trade relationships. 
coefficient. Other changes mostly relate to a small number of variables losing their statistical significance: the LDC dummy becomes insignificant at the 1-digit and 2-digit level of aggregation, and the total number of export products becomes insignificant when we use 1-digit trade data. The latter is not surprising, since there is very little variation among the exporters in the number of exported products if product categories are that highly aggregated.

To summarize, using alternative ways to define a spell, controlling for unobserved heterogeneity by means of fixed rather than random effects, progressively shortening the time period under study, or aggregating the trade data, produces only marginal changes in the results. Overall then, our results can be considered very robust, and in the few instances where changes do occur, we generally obtain the benefit of getting rid of some unexpected results.

\section{Summary and Conclusions}

The objective of this paper is twofold. First, against the background of an existing empirical literature on the duration of trade which has found that international trade is often of strikingly short duration, we aim to establish whether or not EU imports from the rest of the world are also short-lived. Second, since - as we and others argue - there is at this point no clear, commonly accepted theoretical explanation for these short trade durations, we seek to provide a thorough empirical description and analysis of the phenomenon, with the intention of thereby facilitating theoretical developments on the subject.

We employ a rich data set of detailed imports by the EU15 countries from 140 exporters, covering the extended time period 1962-2006. Using these data, we begin by conducting a thorough descriptive analysis of the duration of EU imports, from which we draw several conclusions. First, we find that EU imports are indeed very short-lived - in fact possibly more so than, for example, US imports. The median duration of EU imports is merely one year. Moreover, almost 60 percent of all spells cease during the first year of service, while approximately 75 percent of all trade flows terminate within the first two years and less than ten percent survive the first ten years. The finding that EU imports are very short-lived is upheld when we change the definition of a trade spell, use higher cut-off levels for measuring trade and - remarkably - even when we aggregate trade flows all the way up to the 1-digit SITC level. Second, we find that the duration of trade does not exhibit any long-term upward or downward trend, but remains very stable across the extended time period that we study. This is an interesting empirical finding as many of trade's other characteristics - such as volumes, number of traded products or number of trading partners - have exhibited significant changes over the same time period, as have many of the factors that researchers suspect have an effect on the duration of trade. Third, the short trade durations which have been found in the literature are the result of at least two 
processes: on the one hand countries shifting between different suppliers but continuing to import a given product, and on the other hand countries ceasing to import the product altogether. Fourth, short trade durations are empirically correlated with a lack of export diversification, both in terms of the number of other products the exporter ships and the number of import markets it serves with the given product. No clear evidence is found to connect the level of import diversification to trade durations.

In addition to the descriptive analysis, we also perform a regression analysis. In this, we follow the methodological results in Hess and Persson (2010) and avoid the problematic continuous-time Cox models that have typically been employed in the literature. Instead, we use discrete-time duration models which have been shown to be more appropriate, while taking care to also control for many types of unobserved heterogeneity. The results from our estimations suggest that distance increases the hazard that trade flows die, while a common language or a common colonial history reduces it. Importers with a large GDP face significantly lower hazards, as do exporters with a large GDP if we disregard early data from the 1960s. Contrary to our expectations, least developed countries will, everything else being equal, tend to have more long-lived export spells. Countries with a diversified export structure - either in terms of exporting many products or trading with many importing countries - will have lower hazards than countries which trade few products and/or have few trading partners. If two countries have previously traded a particular product for an extended period of time, this will lower the hazard of the current trade flow dying. If the trade flow has a large initial value, if a differentiated product is involved, or if the total EU market for the product is large, the hazard is decreased. Countries that have already joined the EU will also face a lower risk of bilateral import flows dying. Lastly, just as one would expect, an appreciation of the exporter's (relative) real exchange rate increases the risk that the trade flow will die. 


\section{Appendix: Auxiliary Tables}

Table A.1: Overview of Exporting Countries

\footnotetext{
Afghanistan, Algeria, Angola, Antigua and Barbuda, Argentina, Australia, Bahamas,

Bahrain, Bangladesh, Barbados, Belize, Benin, Bermuda, Bhutan, Bolivia, Brazil,

Brunei, Burkina Faso, Burundi, Cambodia, Cameroon, Canada, Cape Verde,

Central African Republic, Chad, Chile, China, Colombia, Comoros, Congo (Dem. Rep.),

Congo (Rep.), Costa Rica, Côte d'Ivoire, Djibouti, Dominica, Dominican Republic,

Ecuador, Egypt, El Salvador, Equatorial Guinea, Eritrea, Ethiopia, Fiji,

French Polynesia, Gabon, Gambia, Ghana, Greenland, Grenada, Guatemala, Guinea,

Guinea-Bissau, Guyana, Haiti, Honduras, Iceland, India, Indonesia, Iran, Iraq,

Israel, Jamaica, Japan, Jordan, Hong Kong, Kenya, Kiribati, Korea (Rep.), Kuwait,

Lao PDR, Lebanon, Libya, Liberia, Madagascar, Malawi, Malaysia, Maldives, Mali,

Mauritania, Mauritius, Mexico, Mongolia, Morocco, Mozambique, Nepal, New Caledonia,

New Zealand, Nicaragua, Niger, Nigeria, Norway, Oman, Pakistan, Panama,

Papua New Guinea, Paraguay, Peru, Philippines, Qatar, Rwanda, Samoa, San Marino,

São Tomé \& Principe, Saudi Arabia, Senegal, Seychelles, Sierra Leone, Singapore,

Somalia, Southern African Customs Union (Botswana, Lesotho, Namibia, South Africa,

Swaziland), Sri Lanka, St. Kitts \& Nevis, St. Lucia, St. Vincent \& the Grenadines,

Sudan, Suriname, Switzerland, Syria, Tanzania, Thailand, Togo, Tonga, Tunisia,

Trinidad and Tobago, Turkey, Uganda, United Arab Emirates, United States, Uruguay,

Vanuatu, Venezuela, Vietnam, Yemen, Zambia, Zimbabwe
} 
Table A.2: Overview of Variables and Data Sources

\begin{tabular}{|c|c|}
\hline Variable & Definition \& Data Source \\
\hline Trade duration & $\begin{array}{l}\text { Length of trade spell in years. Constructed using 4-digit SITC } \\
\text { (Rev. 1) EU15 imports from the United Nations' Comtrade } \\
\text { (henceforth referred to as the UN Comtrade data). }\end{array}$ \\
\hline Log distance & $\begin{array}{l}\text { Log of distance in km between the trading countries' capitals. } \\
\text { Data from Centre d'études prospectives et d'informations (CEPII), } \\
\text { http://www.cepii.fr. }\end{array}$ \\
\hline Common language & $\begin{array}{l}\text { Takes the value one if the trading countries share the same } \\
\text { language. Data from CEPII, http://www.cepii.fr. }\end{array}$ \\
\hline Colonial history & $\begin{array}{l}\text { Takes the value one if the trading countries have a common } \\
\text { colonial history. Data from CEPII, http://www. cepii.fr. }\end{array}$ \\
\hline Log GDP & $\begin{array}{l}\text { Log of importer's or exporter's GDP. Data from the World Bank's } \\
\text { World Development Indicators (WDI) online. }\end{array}$ \\
\hline Exporter LDC & $\begin{array}{l}\text { Takes the value one if the exporter is classified as a least developed } \\
\text { country by the UN at the end of the time period studied. }\end{array}$ \\
\hline $\begin{array}{l}\text { Log number of } \\
\text { export products }\end{array}$ & $\begin{array}{l}\text { Log of the number of products shipped to any market by the } \\
\text { exporter for every year of the spell. } \\
\text { Constructed using the UN Comtrade data. }\end{array}$ \\
\hline $\begin{array}{l}\text { Number of } \\
\text { export markets }\end{array}$ & $\begin{array}{l}\text { Number of markets to which the exporter ships the given } \\
\text { product for every year of the spell. } \\
\text { Constructed using the UN Comtrade data. }\end{array}$ \\
\hline Lagged duration & $\begin{array}{l}\text { Number of years that a previous spell of the same trade } \\
\text { relationship lasted. Constructed using the UN Comtrade data. }\end{array}$ \\
\hline $\begin{array}{l}\text { Log initial } \\
\text { import value }\end{array}$ & $\begin{array}{l}\text { Log of the value of imports at the beginning of the spell. } \\
\text { Constructed using the UN Comtrade data. }\end{array}$ \\
\hline $\begin{array}{l}\text { Differentiated } \\
\text { product }\end{array}$ & $\begin{array}{l}\text { Takes the value one if the product is classified as differentiated } \\
\text { according to Rauch (1999). } \\
\text { Data from "Jon Haveman's International Trade Data", } \\
\text { http://www.macalester.edu/research/economics/ } \\
\text { page/haveman/trade.resources/tradedata.html. } \\
\text { Concordance used to translate the Rauch classification from } \\
\text { SITC (Rev. 2) to SITC (Rev. 1) from Feenstra (1997), } \\
\text { http://cid.econ.ucdavis.edu/usixd/wp5990d.html. }\end{array}$ \\
\hline $\begin{array}{l}\text { Log total } \\
\text { import value }\end{array}$ & $\begin{array}{l}\text { Log of the total value of imports by all EU15 countries for the } \\
\text { given product and every year of the spell. } \\
\text { Constructed using the UN Comtrade data. }\end{array}$ \\
\hline EU member & $\begin{array}{l}\text { Takes the value one if the importer is an EU member at the } \\
\text { respective duration of the spell. }\end{array}$ \\
\hline $\begin{array}{l}\Delta \text { log relative } \\
\text { real exchange rate }\end{array}$ & $\begin{array}{l}\text { Yearly difference in log relative real exchange rate, where the } \\
\text { relative real exchange rate is defined as nominal exchange rate } \\
\text { (importer currency/exporter currency) adjusted by the respective } \\
\text { consumer price indices and normalized by the average real } \\
\text { exchange rate of all exporting countries against the importing } \\
\text { country. Bilateral real exchange rates have been constructed } \\
\text { using US exchange rates and national consumer price indices } \\
\text { from the World Bank's WDI. }\end{array}$ \\
\hline
\end{tabular}




\section{References}

Baldwin, R. (1988), "Hysteresis in Import Prices: The Beachhead Effect", American Economic Review, vol. 78(4), pp. 773-785.

Baldwin, R. and Krugman, P. (1989), "Persistent Trade Effects of Large Exchange Rate Shocks", Quarterly Journal of Economics, vol. 104(4), pp. 635-654.

Bernard, A. B., Eaton, J., Jensen, J. B. and Kortum, S. (2003), "Plants and Productivity in International Trade", American Economic Review, vol. 93(4), pp. 1268 1290.

Bernard, A. B. and Jensen, J. B. (2004), "Why Some Firms Export", Review of Economics and Statistics, vol. 86(2), pp. 561-569.

Besedeš, T. (2008), "A Search Cost Perspective on Formation and Duration of Trade", Review of International Economics, vol. 16(5), pp. 835-849.

Besedeš, T. and Prusa, T. J. (2006a), "Ins, Outs and the Duration of Trade", Canadian Journal of Economics, vol. 39(1), pp. 266-295.

Besedeš, T. and Prusa, T. J. (2006b), "Product Differentiation and Duration of US Import Trade", Journal of International Economics, vol. 70(2), pp. 339-358.

Besedeš, T. and Prusa, T. J. (2007), "The Role of Extensive and Intensive Margins and Export Growth", NBER Working Paper No. 13628.

Brenton, P., Pierola, M. D. and von Uexküll, E. (2009), "The Life and death of trade flows: understanding the survival rates of developing-country exporters", in R. Newfarmer, W. Shaw and P. Walkenhorst (eds.), Breaking Into New Markets: Emerging Lessons for Export Diversification, pp. 127-144, Washington D.C.: The World Bank.

Brenton, P., Saborowski, C. and von UexkÜll, E. (2009), "What Explains the Low Survival Rate of Developing Country Export Flows", World Bank Policy Research Working Paper No. 4951.

Clerides, S. K., Lach, S. and Tybout, J. R. (1998), "Is Learning by Exporting Important? Micro-Dynamic Evidence from Colombia, Mexico and Morocco", Quarterly Journal of Economics, vol. 113(3), pp. 903-947.

Cox, D. R. (1972), "Regression models and life-tables (with discussion)", Journal of the Royal Statistical Society, Series B, vol. 34(2), pp. 187-220.

Cox, D. R. and OAkes, D. (1984), Analysis of Survival Data, London: Chapman \& Hall/CRC. 
Dixit, A. (1989), "Hysteresis, Import Penetration, and Exchange Rate Pass-Through", Quarterly Journal of Economics, vol. 104(2), pp. 205-228.

Feenstra, R. C. (1997), "U.S. Exports, 1972-1994: With State Exports and other U.S. Data", NBER Working Paper No. 5990.

Fugazza, M. and Molina, A. C. (2009), "The determinants of trade survival", HEID Working Paper No. 05/2009.

Greenaway, D. and Kneller, R. (2007), "Firm Heterogeneity, Exporting and Foreign Direct Investment", Economic Journal, vol. 117, No. 517, pp. F134-F161.

Greenaway, D. and Kneller, R. (2008), "Exporting, Productivity and Agglomeration", European Economic Review, vol. 52(5), pp. 919-939.

Helpman, E., Melitz, M. and Rubinstein, Y. (2008), "Estimating Trade Flows: Trading Partners and Trading Volumes", Quarterly Journal of Economics, vol. 123(2), pp. $441-487$.

Hess, W. and Persson, M. (2010), "The Duration of Trade Revisited. Continuous-Time vs. Discrete-Time Hazards", Working Paper 2010:1, Department of Economics, Lund University.

Jenkins, S. P. (1995), "Easy estimation methods for discrete-time duration models", Oxford Bulletin of Economics and Statistics, vol. 57(1), pp. 129-137.

Kalbfleisch, J. D. and Prentice, R. L. (1980), The Statistical Analysis of Failure Time Data, New York: Wiley.

Kaplan, E. L. and Meier, P. (1958), "Nonparametric estimation from incomplete observations", Journal of the American Statistical Association, vol. 53(282), pp. 457-481.

Martins, P. S. and Yang, Y. (2009), "The Impact of Exporting on Firm Productivity: A Meta-Analysis of the Learning-by-Exporting hypothesis", Review of World Economics, vol. 145(3), pp. 431-445.

MCCALL, B. P. (1994), "Testing the proportional hazards assumption in the presence of unmeasured heterogeneity", Journal of Applied Econometrics, vol. 9, pp. 321-334.

Melitz, M. J. (2003), "The Impact of Trade on Intra-Industry Reallocations and Aggregate Industry Productivity", Econometrica, vol. 71(6), pp. 1695-1725.

Nitsch, V. (2009), "Die Another Day: Duration in German Import Trade", Review of World Economics, vol. 145(1), pp. 133-154. 
RAUCH, J. E. (1999), "Networks versus Markets in International Trade", Journal of International Economics, vol. 48(1), pp. 7-35.

Rauch, J. E. and Watson, J. (2003), "Starting Small in an Unfamiliar Environment", International Journal of Industrial Organization, vol. 21(7), pp. 1021-1042.

Roberts, M. J. and Tybout, J. R. (1997), "The Decision to Export in Colombia: An Empirical Model of Entry with Sunk Costs", American Economic Review, vol. 87(4), pp. $545-564$.

Santos Silva, J. M. C. and Tenreyro, S. (2006), "The Log of Gravity", Review of Economics and Statistics, vol. 88(4), pp. 641-658.

Sueyoshi, G. T. (1995), "A class of binary response models for grouped duration data", Journal of Applied Econometrics, vol. 10(4), pp. 411-431.

VAN DEN BerG, G. J. (2001), "Duration models: specification, identification, and multiple durations", in J. J. Heckman and E. Leamer (eds.), Handbook of Econometrics, vol. 5, pp. 3381-3460, Amsterdam: North-Holland.

Vernon, R. (1966), "International Investment and International Trade in the Product Cycle", Quarterly Journal of Economics, vol. 80(2), pp. 190-207.

Wagner, J. (2007), "Exports and Productivity: A Survey of the Evidence from Firm-level Data", World Economy, vol. 30(1), pp. 60-82.

Yeaple, S. R. (2005), "A Simple Model with Firm Heterogeneity, International Trade, and Wages", Journal of International Economics, vol. 65(1), pp. 1-20. 